\title{
Contractual Liability and the Theory of Contract Law
}

Nick Sage

Department of Law, The London School of Economics and Political Science, London, UK

n.sage@1se.ac.uk

Houghton St, London WC2A 2AE

07403434577 


\section{Contractual Liability and the Theory of Contract Law}

This article considers the character of contractual liability and its implications for theories of contract law. Contractual liability has seemed to legal theorists to stand in need of explanation because it is 'strict': a contracting party may be answerable for breach regardless of whether her conduct is faulty. In efforts to account for this approach, theorists have invoked a number of well-known general theories of contract, including Holmesian, economic, moral, voluntarist (or choice-based) and rights-based theories. The article contends that none of the existing theories is fully satisfactory. To develop an alternative account, the article suggests we should reconsider the nature of contractual liability in the common law, attending more closely to certain features that theorists have so far tended to overlook. Having done this we will be able to see that another very well-known general theory is capable of accounting for the standard of contractual liability: the theory of contract as promise.

Article word count: 12,926 words exclusive of footnotes

(KLJ word limit: typically 12,000 words exclusive of footnotes)

Contractual liability has recently captured the attention of legal theorists.1 They have begun to ask: why is liability for breach of contract 'strict': why may a party be liable regardless of any faulty conduct on her part? Perhaps the law should adopt a more forgiving standard. Certainly in other areas of private law, especially tort, strict liability is usually thought to stand in need of special explanation or justification.

In their efforts to account for strict contractual liability, theorists have brought to bear a number of perspectives familiar from the theory of contract law more generally. According to the Holmesian account, strict liability arises because a contracting party has a sort of dual obligation: to perform, or else to pay damages in the event of nonperformance. Instrumental accounts view strict liability as a means to the realisation of a desirable end, such as economic

1 The leading theoretical accounts are discussed below. The issue was raised earlier by comparative legal scholars, eg FH Lawson, 'Fault and Contract-A Few Comparisons' (1975) 49 Tulane Law Review 295, who noted that some civilian systems profess to require fault before imposing contractual liability, thus calling into question the common law approach. The present article focuses on the common law and its theoretical implications. 
efficiency or a moral good. A voluntarist account suggests that contracting parties choose to be subject to a strict liability standard. Rights-based accounts contend that strict liability follows from the need to vindicate a party's right to contractual performance.

This article seeks to contribute to our understanding of contractual liability and to the ongoing debate about the relative merits of some of today's leading contract theories. The article first considers the existing theories of contractual liability. It concludes that the Holmesian, instrumental and voluntarist accounts all suffer from similar difficulties. The rights-based account can avoid those difficulties, but it faces other problems of its own.

The article then suggests that reflection on the difficulties that afflict the rights-based theory should prompt us to reconsider the proper target of a theory of contractual liability. That is, we should reflect more closely on the character of the liability standard that actually appears in the common law of contract, in order to identify what is truly distinctive about it. The article proceeds to develop a new understanding of contractual liability, which attends to aspects of it that theorists have tended to overlook.

Once we attain a better understanding of the special character of contractual liability, the article contends, an alternative account of the phenomenon should fall into place. 2 The article concludes by advancing an account based upon another very well-known general theory of contract law: the theory of contract as promise.

The article does not seek to provide the last word in the debate about how to understand contractual liability. Still less, the last word on broader debates about the nature of contract and the merits of various general theories. Instead the aim is merely to illuminate some of the issues at stake in these debates and to open up some potentially fruitful lines of further theoretical inquiry. 


\section{Existing accounts of contractual liability}

Contractual liability is often said to be 'strict' rather than 'fault-based'.3 Recently a number of leading contract theorists have noticed this and have endeavoured to explain why it should be the case. These theorists generally take 'fault' to refer to conduct that is intentional, reckless, careless or otherwise unreasonable.4 (Or perhaps, conduct that is accompanied by some other culpable mental state, or which fails to meet some other standard of justification.) Whereas a 'strict' liability approach ignores such factors.

The apparently 'strict' standard of liability in contract law attracts theorists' attention for a number of reasons. Not least, because other areas of private law-perhaps most prominently the tort of negligence — seem to require fault before imposing liability. 'Why', theorists are prompted to ask, 'is a different standard applied to contractual obligations?'5 Relatedly, strict liability seems more difficult to justify than fault-based liability. In part for this reason, contractual liability seems to present a 'philosophically interesting' challenge for legal theorists.6 Presumably one significant virtue of a comprehensive theory of contract law would be its ability to account for this phenomenon.

In their efforts to understand the 'strict' standard of liability for contractual breach, theorists have brought to bear a number of general theories of contract law. The article will now consider these and conclude that each is, in certain respects, less than fully satisfactory. The aim of the discussion here is not to provide knock-down arguments against any theory. It is only to identify certain revealing common difficulties that existing accounts face, reflection on which will point the way towards the development of an alternative approach.

\footnotetext{
3 Eg Smith, ibid 376, citing Raineri v Miles [1981] AC 1050, 1086; American Law Institute, Restatement (Second) of Contracts (1981) ch 11, introductory note.

4 See notes 9, 18, 22, 34, 37 below, and accompanying text.

5 Smith $n 2$ above, 376.

6 Seana Valentine Shiffrin, 'Enhancing Moral Relationships Through Strict Liability' (2016) 66 University of Toronto Law Journal 353, 355.
} 
In an effort to bring out the relevant issues more clearly, the article will distinguish a number of existing theoretical approaches and discuss them separately. However, it should be noted at the outset that many individual scholars advance accounts that do not fit neatly into any one theoretical box. When individual scholars are discussed below the point of doing so is certainly not to pigeonhole them, but rather to draw out important insights from their work.

\subsection{The Holmesian account}

One prominent existing account of 'strict' contractual liability is what we may call the 'Holmesian' account. Oliver Wendell Holmes, notoriously, suggested that a contracting party acquires a sort of dual or conditional obligation: a primary obligation to perform, coupled with a secondary obligation, in the event she does not perform, to pay a money sum equivalent to expectation damages.7 In more recent times, Holmes'suggestion has been deployed by Stephen Smith in order to explain why contractual liability appears to be 'strict'.8

Smith argues that a contracting party acquires a Holmesian dual or conditional obligation, and that this produces the appearance of strict liability in contract law-even though the law's actual liability standard is fault-based. (That is, a standard requiring intentional or careless breach.)9 To see how this could be the case, Smith invites us to distinguish two situations. On the one hand, he asks us to imagine that a contracting party fails to meet her primary obligation to perform, and does so in a faulty manner. In such a case, she can of course be held liable, and subjected to an order of specific performance or damages, under the fault-

\footnotetext{
7 Oliver Wendell Holmes, 'The Path of the Law' (1897) 10 Harvard Law Review 457, 462; OW Holmes, The Common Law (Boston: Little, Brown, \& Co, 1881) 301. See further Daniel Markovits and Alan Schwartz, 'The Myth of Efficient Breach' (2011) 97 Yale Law Journal 1939, 1981-1982.

${ }_{8}$ Smith $\mathrm{n} 2$ above, 384-386. The article focuses on Smith rather than other Holmesian theorists because Smith addresses the particular issue of the contractual liability standard.

Note that some Holmesian theories of contract are 'disjunctive': the promisor is regarded as having a pure option either to perform or breach. Smith's is 'conjunctive': the promisor is actually bound to perform (an obligation excused only by faultless breach) and, in the event of nonperformance, to pay damages.

We need not consider here whether the promisor's 'dual obligation' should be ascribed to her voluntary choice or to a legal rule independent of her choice. This does not affect the essence of the Holmesian account, though either approach could raise further difficulties for it. 9 ibid 376.
} 
based liability standard. What if, on the other hand, a contracting party fails to meet her primary obligation to perform in a faultless manner? Then she cannot be held liable under the faultbased standard. However, the party's innocent failure to perform her primary obligation will trigger her secondary, conditional contractual obligation: to pay a money sum equivalent to expectation damages. Thus, whether she behaves faultily or not, the contracting party will be required to redress her nonperformance.

Smith's account is an ingenious deployment of a Holmesian conception of contract in an effort to show that the supposedly 'strict' standard we seem to find in the law is in fact a misleading appearance produced by other factors. However, upon closer inspection, Smith's account faces substantial difficulties. Notably, these are analogous to well-known difficulties that afflict Holmesian theories of contract more generally.

As an initial matter, Holmesian theories of contract generally have difficulty accounting for some of the normative language we tend to use in this context.10 We tend to speak for example of a party's contractual obligation to perform being breached, such that a damages remedy is called for. On the Holmesian account, however, it is not obvious that such language is appropriate. Because on this view a party who has to pay money in the event of nonperformance is merely performing her contract-her conditional secondary obligation. Similarly, on Smith's account—which assumes an underlying fault-based liability standarda party who faultlessly fails to perform, and who then has to pay money compensation, is not being subjected to a remedy for a breach of her primary contractual obligation.11 She is merely performing the secondary aspect of her conditional contractual commitment. Thus, Smith's account seems to efface normative notions associated with our ordinary understanding of

10 Of course Holmes himself regarded this as a virtue, since he thought that 'In the law of contract the use of moral phraseology has led to ... confusion'. 'The Path of the Law', n 7 above, 463.

11 A point Smith himself raises. Note 2 above, 381, 386. 
contract: that of a genuine obligation to perform, which may be breached, such that a remedy is called for.

Holmesian theories of contract law in general also have difficulty explaining why courts sometimes order specific performance rather than allowing a party to breach and pay damages.12 Smith's account of contractual liability suffers from a similar difficulty: it cannot explain all awards of specific performance. Since Smith assumes that contract law's liability standard is fault-based, he cannot explain why a court would order specific performance in response to a party's faultless breach of her primary obligation to perform. To explain such awards, some supplementary theoretical account must be roped in. Indeed, to account for specific performance Smith himself turns to a rights-based theory.13 (We will consider this aspect of his account later on.)

Finally, Holmesian theories generally also have trouble explaining why a party who sues for breach of contract need not allege or establish that her counterparty has failed to tender money compensation to her.14 On the Holmesian view, a court should presumably require a contractual claimant to show that her counterparty's conditional, secondary obligation to pay money has in fact been breached. Similarly, on Smith's account of contractual liability—which assumes a fault-based liability standard - a court should presumably require the contractual claimant to show that her counterparty has faultily failed to tender money compensation. Yet in the law of contract as we know it, a court need not establish that a party has faultily failed to tender money before holding her liable for a breach of contract and awarding a monetary remedy. 15

12 Willard T. Barbour, 'The "Right” to Break a Contract' (1917) 16 Michigan Law Review 106 (note). 13 Smith n 2 above, 378-379, 384-386.

14 Letter from Sir Frederick Pollock to Oliver Wendell Holmes (29 Nov 1928), in Mark DeWolfe Howe (ed), The Holmes-Pollock Letters, vol 2 (Cambridge, Mass: HUP, 1942) 233 ('Don't you want an averment of neither performance nor tender of damages [?]').

15 Smith notes that the promisor's payment of compensation may be excused by her insolvency. Note 2 above, 385-386. However, the very determination that she is insolvent presupposes her contractual liability to pay. 
The underlying source of these difficulties — both for Holmesian theories generally and for Smith's account of strict liability in particular-is the same. This kind of account denies that a contractual obligation to perform has an unconditional or inherent moral significance, which is reflected in contract law's liability regime. Instead, Holmesians view contractual liability as arising only conditionally_out of the failure to respect a secondary, remedial commitment that is triggered by contractual nonperformance.

None of this is to suggest that a Holmesian approach to contractual liability—let alone a Holmesian approach more generally_is undesirable all things considered. Such an approach has many merits that may outweigh the difficulties mentioned here. The point of discussing these difficulties is just to begin to bring out a common set of challenges that afflict many existing accounts of contractual liability, and which will be addressed by the alternative account developed later on.

\subsection{Instrumental accounts}

Another approach to 'strict' liability would be to justify it instrumentally, as a means for bringing about an independently valuable end. That is, an end we might understand and value even if there were no doctrine of strict liability, or indeed no institution of contract. 16 The main candidates for an instrumental theory of strict liability are economic and moral accounts. It will now be suggested that such accounts encounter significant difficulties. Again, these are variations on well-known difficulties that arise for instrumental theories of contract law more generally.

Legal economists consider whether the rules of contract law incentivise individuals to behave in ways that yield the most overall value. The best-known economic account of contract is the basic theory of 'efficient breach' — which happily, as Eric Posner points out, provides an

16 For this understanding of instrumentalism see eg Peter Benson, 'Abstract Right and the Possibility of a Nondistributive Conception of Contract' (1989) 10 Cardozo Law Review 1077, 1153; Ernest J Weinrib, The Idea of Private Law (Cambridge, Mass: HUP, 1995) 49-50; Martin Stone, 'Legal Positivism as an Idea about Morality' (2011) 61 UTLJ 314, 315. 
entrée to the economic analysis of strict liability.17 The basic efficient breach theory concerns the incentive effects of expectation damages on a contracting party's decision whether to perform or breach. Economists can recommend this remedy as efficient because it forces the party, when deciding whether to perform or breach, to take into account the losses her breach will inflict upon the other party-since she must effectively cover those losses by paying expectation damages. A rational party will then breach only if the benefits she gains from doing so outweigh the losses inflicted upon the other party.

The thing to notice about the basic efficient breach theory, for present purposes, is that it presupposes a sort of strict liability standard. 18 It presupposes that a contracting party is liable to pay damages in the event of breach irrespective of why the breach occurred. Thus, economists can recommend this liability standard as efficient when combined with expectation damages. 19

A moral instrumental account of strict liability can be gleaned from the work of Seana Shiffrin.20 Shiffrin gives a reason for recommending strict contractual liability that is on the face of it surprising. She suggests that this form of liability promotes 'morally healthy relationships'. By a 'morally healthy relationship', however, Shiffrin has something quite specific in mind: a relationship in which the party owed a contractual performance leaves it up to the other party to perform — rather than scrutinising and second-guessing her wherewithal or commitment, or engaging in his own, potentially conflicting, efforts to ensure performance

17 Eric A Posner, 'Fault in Contract Law' in Omri Ben-Shahar and Ariel Porat (eds), Fault in American Contract Law (Cambridge: CUP, 2010). For other economic treatments of the issue see the other contributions to the same volume.

18 Indeed, an 'absolute' liability standard: one that does not allow for frustration. Posner does not define 'faultbased' liability, but he seems to have in mind any rule that allows the promisor to escape liability for nonperformance. (While he categorises 'faulty' conduct as 'willful', 'negligent', or 'inadvertent', he defines those terms purely by reference to the costs of performance and nonperformance, ibid 71.)

19At least, economists can recommend the standard, with respect to the promisor's performance/breach decision, insofar as it affects the contracting parties. The analysis becomes more complex if one considers other decision points, decision-makers and effects.

20 Shiffrin $n 6$ above. 
occurs.21 Shiffrin suggests that strict liability might promote 'morally healthy relationships', in this sense, by assuaging a contractual obligee's concern that his counterparty might fail to perform. Given a strict liability standard, a contractual obligor will be held liable for and ordered to repair her breach, regardless of whether it was intentional, reckless, or negligent.22 Hence the obligee will be less inclined to scrutinise and second-guess her performance efforts.

Shiffrin's account of strict liability is susceptible of various interpretations. Moreover, her rich and extensive body of work on contract more generally contains many complex ideas and certainly cannot be reduced to the above summary. At least on one reading, however, Shiffrin can be understood to offer a moral account of strict liability in contract law that is instrumental in form. It would seem that one could value the kind of 'morally healthy relationship' Shiffrin identifies irrespective of whether a 'strict' standard of liability existed.23 On this reading, then, Shiffrin posits an independently valuable end, to which the rule of strict liability can be regarded as a means.

Though economic and moral instrumental accounts yield valuable insights, it should not be controversial to say that neither provides a fully satisfactory account of strict liability. These accounts strike difficulties of the kind faced by any instrumental account of contract.24 In essence the difficulty is this. Since an instrumental account views a given rule of contract law,

\footnotetext{
21 ibid 365-371.

22 See ibid 357.

23 It might be suggested that 'strict' liability and 'morally healthy relationships' cannot be grasped independently of each other, but rather stand for example in a relation of constitution (whereby strict liability is part of what it is for two parties to stand in a morally healthy relationship). This interpretation would require us to modify Shiffrin's own specifications of the respective concepts, which, as they stand, seem to be independently specifiable. (On the one hand, liability regardless of intention, recklessness or negligence; and on the other, the absence of second-guessing and the undertaking of potentially conflicting efforts.) It is unclear how one could modify the respective concepts so that they are not independently conceivable while retaining an intelligible theory that resembles Shiffrin's argument. But in any event, the key point of the discussion here is not to pigeonhole Shiffrin, but to use her illuminating discussion to bring out some characteristic difficulties that afflict theories of contractual liability that are instrumental in form.

24 'Two-level' instrumental accounts (such as rule-utilitarianism) will face variations on the same difficulties, but such accounts will not be discussed here.
} 
not as valuable in itself, but as useful due to its tendency to promote some other value, the account is pervaded by contingency. This contingency manifests itself in various ways.

First, the adoption of a given instrumental end is contingent upon our views about what ends are worth pursuing. Thus, an economic analysis assumes that contract law should aim to optimise incentives for the production of value, which is of course controversial. Shiffrin's moral account assumes that contract law should promote morally healthy relationships of the kind she identifies. Others might think the law should promote a different moral end-perhaps, say, vigilant self-protection.

Second, the efficacy of a given means for bringing about the proposed end is contingent upon the circumstances. Even if contract law aims to provide appropriate incentives for a party's performance/breach decision, a combination of strict liability and expectation damages will not always provide the right incentives. The efficacy of that combination holds only ceteris paribus. For example, it may not hold if the party's performance/breach decision affects the value that accrues, not just to herself and the promisee, but to third parties. Likewise, strict liability will not always bring about Shiffrin's morally healthy relationships. For example, if one party is concerned that the other may be judgment-proof.

Third, the desirability of the proposed means is contingent. Why adopt a strict liability rule to achieve our end when other means may be just as effective? As Eric Posner points out, a variety of liability rules may bring about an efficient performance/breach decision. Consider the following simple, efficient, non-strict liability rule: a party is absolved of liability if her decision to breach is efficient.25 Similarly, Shiffrin's morally healthy relationships might be achieved using means other than strict liability. Perhaps contracting parties could take out insurance policies against breach. 
In all of these ways, then, an instrumental account is arguably less than fully satisfactory because it is pervaded by contingency.26 What is the source of this problem? It arises because instrumental accounts — of contract generally and of strict liability in particular-decline to regard the rules of contract law as having intrinsic moral significance. (Such accounts instead view the rules of contract law as a useful means for producing other things that are of independent value.) Thus, we here encounter a variation on the same difficulty that we previously saw afflict the Holmesian theory.

Again, it is important not to make too much of the criticism here. Instrumental accounts of contract law and of strict liability in particular of course have many important virtues. Indeed, for any given area of law an instrumental account may turn out to be the best on offer. Nevertheless, we are beginning to see the outline of an alternative form that another account of contractual liability might take.

\subsection{Voluntarist accounts}

One might suppose that strict liability for breach of contract is self-imposed, arising from the voluntary undertakings of contracting parties.27 However, a voluntarist account of strict liability too strikes substantial difficulties. These are akin to well-known difficulties that arise, as Hume pointed out, for any theory of 'voluntary obligation'. One way to bring out some of these difficulties is to notice that a voluntarist account, depending upon how it is understood, is either implausible, or else plausible but unenlightening.

Philosophers and legal theorists from Hume onwards have noticed that a voluntarist account of a normative obligation, such as a promissory or contractual obligation, seems implausible if the idea is meant to be that an individual person just arbitrarily chooses to be

\footnotetext{
26 From the perspective of an instrumental account the existence of the means is also contingent. (How did the strict liability rule come to exist such that it is available for use as an instrument?)

27 See Smith $n 2$ above, 379-380. He rejects this view for reasons that share the same spirit as those given above. Note the objections here do not necessarily apply to a voluntarist version of the Holmesian account. Cf note 8 . The article's case against the Holmesian view rests on the reasons given previously.
} 
subject to the relevant obligation. Much as someone might choose, say, to paint her living room wall a certain colour. On such a view, the voluntary undertaking of an obligation would be a matter of mere individual fiat. The problem is that this view gives us no reason to suppose that a person's purported undertaking of an obligation is actually effective to create the obligation that she seeks.28 Why would a person's arbitrary whim bring about a normative change in what she is required to do? In general, individual fiat does not suffice to determine the norms that apply to people. If, for example, I declare that I am obliged to paint my house tangerine, or that someone else is obliged to hand me their wallet, there is no reason to suppose I have succeeded.

For the same reason, a voluntarist account of the 'strict' liability standard in contract law is implausible if the idea is meant to be that a contracting party has some sort of ungrounded power to choose the standard of liability that applies to her. On such an approach we have no reason to suppose that the party's arbitrary whim would be effective to establish the desired kind of liability.

On another construal, a voluntarist account might be entirely plausible, but unenlightening. This would be the case if there is an objective norm or rule, which provides that certain voluntary undertakings will achieve their desired effect. For example, there might be an objective rule of morality or positive law, which permits parties to change their normative situation by manifesting their choice in a prescribed manner. Given such a rule, we would have reason to suppose that the individual's voluntary undertaking succeeds in achieving the desired effect. Thus, a rule-based version of a voluntarist account is entirely plausible. But at the same time, it is largely unenlightening. Because now, the appeal to an individual's 'voluntary undertaking' does not really help us understand what is going on. To do so, we would presumably have to say something about the objective norm or rule that gives the individual's 
voluntary undertaking its effect. To invoke a well-worn analogy: a baseball player who steals second base usually does so voluntarily.29 Furthermore, by taking the base she produces certain normative effects, such as the ability and obligation to move on to third. The player usually chooses to produce those effects. Yet if a spectator unfamiliar with baseball asks why a player who has taken second is allowed or obliged to move on to third, it is not helpful to reply that this is because of the player's voluntary act. We must offer some account of the rules of baseball that endow the voluntary act with normative consequences.

Now, one might suppose that at least in the contractual context there is an obvious candidate for an objective norm or rule that could make a party's voluntary undertaking of 'strict' liability effective. Perhaps there is simply a rule that courts should respect the voluntary choices of contracting parties? So that, if a party chooses to be strictly liable, her choice will be respected. This approach might appear to give us a simple way of explaining contractual liability. Further reflection, however, shows that it will not work. The rule that a contracting party's choices should be respected, when applied to her purported choice of a strict liability standard, prompts the question: in exactly what way should her choice of a liability standard be respected - strictly, or otherwise? We cannot presuppose that her choice should be strictly enforced, because that is what we are trying to explain.

The foregoing discussion has not attempted to discuss all of the challenges that voluntarist theories face, let alone to consider all of the possible responses to those challenges. Later we will return to the voluntarist theory of contractual liability-as well as the other theories discussed so far - to contrast it with the alternative theory developed later. The point

29 From John Rawls, 'Two Concepts of Rules' (1955) 64 Philosophical Review 3, 25. This article will not consider whether a party might voluntarily establish strict liability not by undertaking it directly but by inducing some form of reliance or belief in the other party. Cf Neil MacCormick, 'Voluntary Obligations and Normative Powers (Part I)' (1972) 46 Proceedings of the Aristotelian Society (Supp Vol) 59; Thomas Scanlon, 'Promises and Practices' (1990) 19 Philosophy and Public Affairs 199. Nobody has suggested such an account of strict liability. In any event such accounts are subject to well-known objections. In particular, they arguably generate only some limited form of protection for a party's reliance or belief. 
at this stage is just that the application of a voluntarist theory to the problem of the contractual liability standard raises certain difficulties, which are analogous to familiar difficulties that such a theory encounters more generally. Furthermore, the root source of these difficulties should already be familiar given our previous discussion. They arise because a voluntarist theory does not purport to understand contractual liability by elucidating the inherent normative significance of a contractual obligation and the associated form of liability, but by appealing to something else: the desires or choices of individuals.

\subsection{Rights-based accounts}

All of the theories discussed so far have struck difficulties because they decline to regard a contractual obligation to perform as having unconditional moral significance. Holmesians, notoriously, deny that a contracting party has an unconditional obligation to perform. Instrumentalists view contractual obligations as useful for producing other things of value. Voluntarists attribute contractual obligations to what contracting parties happen to desire. Each of these theories, when applied to the particular issue of contractual liability, appears to strike difficulties for a related reason. None of the theories seeks to link the contractual liability standard to the inherently normative character of a contractual obligation to perform. For Holmesians, the appearance of 'strict' contractual liability arises only as a consequence of a contracting party's secondary remedial obligation. Instrumentalists seek to understand strict liability by reference to the independently valuable economic or moral goods it might promote and voluntarists by appealing to the parties' desires or choices.

All of this might prompt us to look, for an understanding of contractual liability, to a theory that does accept the inherent normative significance of a contractual obligation to perform, and which seeks to show that the law's liability standard follows from the nature of that obligation. The leading existing account of this kind is a rights-based theory. 
Although rights-based accounts of contractual liability avoid some of the difficulties that afflict other theories, as we shall see they face problems of their own. It will be worth considering these in some detail, and not only because rights-based accounts of contract law generally are very influential in contemporary scholarship.30 The discussion will prompt us to reconsider the proper target of a theory of contractual liability - the precise character of the liability standard that appears in the law — and thereby pave the way for an alternative account of that standard.

\subsubsection{The key features of a rights-based account}

A rights-based theory of contract, in general, accounts for the inherent normative force of a contractual obligation to perform by positing that a valid contract confers a right to the contractual performance. On this view, a party who contracts 'for the construction of a garden shed'- to use an example of Dori Kimel's - acquires a right to the construction of a garden shed.31

As Kimel and others point out, a rights-based theory of contract generally is attractive not least because it helps to reconcile judicial intervention in contract cases with the "harm principle'. Theorists have long worried that the standard contractual remedies, specific performance and expectation damages, do not seem to redress any harm that has actually been suffered, but rather force one contracting party to confer a benefit on the other.32 However, if a contract creates a right or entitlement to contractual performance, a breach of contract can be

30 In addition to the work discussed below, see eg Randy E Barnett, 'A Consent Theory of Contract' (1986) 86 Columbia Law Review 269; Daniel Friedmann, 'The Performance Interest in Contract Damages' (1995) 111 LQR 628; Stephen A Smith, 'Towards a Theory of Contract' in Jeremy Horder (ed), Oxford Essays in Jurisprudence: Fourth Series (Oxford: OUP, 2000); Peter Benson, 'The Unity of Contract Law' in Peter Benson (ed), The Theory of Contract Law (Oxford: OUP, 2001); Andrew Gold, 'A Property Theory of Contract' (2009) 103 Northwestern University Law Review 1; Ernest J Weinrib, Corrective Justice (Oxford: OUP, 2012) ch 5.

31 Dori Kimel, 'The Morality of Contract and Moral Culpability in Breach' (2010) 21 King's Law Journal 213, 219. See also 'Fault and Harm in Breach of Contract' in Ben-Shahar and Porat $n 17$ above; 'Personal Autonomy and Change of Mind in Promise and in Contract', in Gregory Klass, George Letsas and Prince Saprai (eds), Philosophical Foundations of Contract Law (Oxford: OUP, 2014).

32 Eg LL Fuller and William R Perdue, Jr, 'The Reliance Interest in Contract Damages: 1' (1936) 46 Yale Law Journal 52, 56ff. 
understood as the infliction of a harm. On this view, a breach of contract denies a party something to which he is entitled, and 'denying a party something of value to which [he] is entitled is harming (and paradigmatically so)'.33 Furthermore, it seems appropriate for a court to intervene to remedy this harm, either by ordering specific performance of the contract, or by requiring a payment of expectation damages designed to make it as if performance had occurred. If, for example, a contracted-for garden shed is not provided, the party entitled to it thereby suffers a harm in that he is denied his shed, which should be remedied by requiring the other party to provide the shed or its money equivalent.

In addition to its more general virtues a rights-based theory might be thought, Kimel notes, to account for 'strict' contractual liability-liability that is not based on intention, recklessness, or carelessness for example.34 As we have already seen, if a contracting party has a right to performance, the other party's breach amounts to a violation of that right, which a court should remedy by requiring performance or payment of a money equivalent. Moreover, Kimel points out, this reasoning seems to hold regardless of whether the breach is faulty. A contractual breach harms the innocent party, by depriving him of his entitlement to performance, whether or not the breach is accompanied by fault. The innocent party suffers the same harm either way. It follows, Kimel suggests, that a contractual party should be required to remedy the harm done by her breach irrespective of the culpability of her conduct. If she is contractually obliged to provide a garden shed, she should be strictly liable to do so.

[T] he harm against which parties ought to be protected in the [contractual] context ... namely, the denial of valuable contractual entitlements ... tends to be entirely insensitive to fault ... Whether non-performance ... would cause that harm — that is, would leave the innocent party in an inferior position to that in which performance would have left it,

\footnotetext{
33 'Morality of Contract' n 31 above, 223 (emphasis in the original).

34 In another piece Kimel opposes strict liability to 'fault-based' liability, which includes liability based on 'intention, knowledge, inappropriate motive, recklessness, [or] negligence' i.e. 'unreasonable risk-taking'. 'Personal Autonomy' n 31 above, 105.
} 
denying it some or all benefits of the bargain - is a question the answer to which depends entirely on matters other than the moral culpability, if any, attending the breach ...35

In this way Kimel lucidly articulates the key ideas of a rights-based account of contractual liability. This is not to suggest that Kimel's own views can be reduced to the above summary — indeed, the key ideas just described have been deliberately isolated from his much broader and richer theory of contract law as a whole, which cannot be done justice here.36 Essentially the same key ideas can also be found in the work of other theorists, such as Stephen Smith and Curtis Bridgeman, who also offer rights-based accounts of strict liability.37 Although Smith, as we have seen, invokes a rights-based theory only for specific performance, appealing to a Holmesian theory to explain damages. And Bridgeman, as we shall see, combines the rights-based theory with voluntarist ideas.

\subsubsection{Difficulties for a rights-based account}

Further reflection shows that, despite its significant virtues, a rights-based account of contractual liability is somewhat puzzling. This is because nothing about the existence of a right, as such, entails that liability for deprivation of the right should be independent of 'fault' - in the sense of careless or intentional conduct for example.

For one thing, liability for a rights violation sometimes requires a showing of carelessness or negligence. To see this, consider another kind of right: a property right. Let us assume that you have a property right to a garden shed, and that you are deprived of the subjectmatter of your right because the shed is destroyed by fire. Now no doubt, as Kimel suggests, you are 'harmed' in this situation, in the sense that you are have suffered 'the denial of a valuable entitlement'. No doubt, as Kimel also suggests, this harm occurs regardless of whether

\footnotetext{
35 ibid 225.

36 See further Dori Kimel, From Promise to Contract (Oxford: OUP, 2003).

37 Smith, Contract Theory n 2 above; Curtis Bridgeman, 'Reconciling Strict Liability with Corrective Justice in Contract Law' (2007) 75 Fordham Law Review 3013. Bridgeman suggests that 'fault-based' liability would inquire into intention, wilfulness, or deliberateness, negligence, lack of best efforts, or the justifiability of breach. ibid 3014, 3017.
} 
it is attributable to my carelessness. You suffer the same harm either way. Still, it does not follow that I should be liable for your harm, regardless of whether I have been careless. In fact, in the law as we know it liability in this situation often depends upon an inquiry into carelessness or unreasonableness. Most obviously this is true of an action in the tort of negligence for damage to property. Here I will escape liability for the destruction of the shed to which you have a property right if, say, I took reasonable precautions to avoid setting it alight. (Or for that matter, if the shed was struck by lightning, or if you set fire to it yourself.) Perhaps the rights-based theory could be salvaged by analogising a breach of contract, not to a case where someone's property is damaged, but to a case in which one person detains another's property? We might think of a party who has breached a contract as having detained the object of her counterparty's contractual right. Just as someone might detain an object over which another person has a property right. In this kind of situation, 'strict' liability is arguably more appropriate. Indeed, a 'strict' standard seems to apply in at least some areas of the common law that govern this kind of situation, such as the tort of trespass to goods. Stephen Smith explicitly advances this version of a rights-based view of contractual liability:

[On a rights-based view of contractual liability] courts are essentially determining who owns what in contract cases, and then telling non-owners to give the owners what they own. That the non-owner may not be at fault is therefore irrelevant. If I accidentally take your umbrella, I have to give it back; it is no defence that I made an entirely innocent mistake or even that you were at fault for leaving your umbrella where you did. On the same basis, it might be argued that if I have sold goods to you and failed to deliver them, regardless of the reason for non-delivery, the goods belong to you and I must give them to you. It makes no difference that I am at fault for the non-delivery. 38

38 Smith, Contract Theory n 2 above, 378-379. Smith proceeds to analogise the law of unjust enrichment. See also Bridgeman n 37 above, 3023-3025, analogising the defendant's liability for using the plaintiff's wharf in Vincent $v$ Lake Erie Transportation (1910) 123 NW 221. Although Smith limits the rights-based account to awards of specific performance, it cannot explain specific performance cases that do not involve the detention of an object. 
However, this version of a rights-based account is also problematic. Liability for detaining another's object of property, for example taking another person's umbrella, would seem to require the defendant to undertake a certain sort of action or activity: taking possession of the object in question. But if so, this form of liability is not 'strict' in the same way as contractual liability. Liability for breach of contract does not essentially require any act by the breaching party such as taking possession of an object. Indeed, a party may be liable for a breach of contract where there exists no object she might conceivably be said to detain, for example where she fails to provide a contractual service. 39

Thus, the difficulty with a rights-based approach is that it suggests (implicitly or explicitly) that contractual liability should be similar to liability for the breach of other kinds of rights. In particular, this approach suggests that contractual liability might be similar to liability for a 'strict' liability proprietary tort. However, that overlooks important differences between contractual liability and the law's treatment of liability in other contexts. The upshot is that, to develop a more satisfactory theory, it would seem, we need to get clearer about the character of contractual liability. Only then will we be in a position to develop a theory that persuasively accounts for this legal phenomenon and does not risk conflating it with different approaches to liability in other areas of the law.

Before moving on, it is worth mentioning, if only to dismiss, one other reason rightsbased theorists have given for supposing that liability for the breach of a contractual right, as opposed to another kind of right such as a property right, should be 'strict'. One might suppose that a contracting party should be strictly liable because she voluntarily consents to the creation of the contractual right. Hence Curtis Bridgeman suggests that a contracting party ought to be held liable for a breach of the other party's right because she 'freely assumes responsibility by fact of non-delivery, rather than any act of detention on her part, that triggers her liability. 
entering into [the] contract' that creates the right in the first place. 40 But while there may well be something to the idea that a contracting party freely assumes a responsibility in contract formation (to which we will return below below), this idea cannot salvage a rights-based account of contractual liability. If the idea is that a contracting party voluntarily assumes a responsibility, in addition to conferring a right on the other party, we no longer have a purely rights-based theory. If, on the other hand, the idea is that a contracting party's assumption of responsibility consists in her conferral of a right upon the other, we have not accounted for contractual liability. Because it does not follow, if one person confers a right on another, that she should be liable when something later goes wrong with the subject-matter of the right, irrespective of her intention or negligence. Again consider an equivalent case involving a property right. I sculpt a vase and give it to you, such that you have a right to the vase. If the vase later shatters, I am not necessarily liable. Without more information it is unclear who, if anyone, ought to be. Indeed, before holding anyone liable in an actual property destruction case of this kind a court will investigate whether the breakage was brought about by her intentional or unreasonable or otherwise illegitimate conduct.41

\footnotetext{
40 Bridgeman n 37 above, 3022.

${ }_{41}$ Compare Ernest Weinrib's response to Richard Epstein's rights-based argument for 'strict' liability in tort. Idea of Private Law n 16 above, 175-177.

Some other possible variants of a rights-based account should be noted. First, could strict liability be generated if we assume that a contracting party acquires a right to an act? (This is the preferred view of some proponents of rights-based theories of contract generally, such as Ernest Weinrib and Andrew Gold, note 30 above.) On this view, a contract would never confer a mere right to a garden shed, but might confer a right, say, to the construction of a shed by the other party. However, this view does not explain strict liability. It does not follow, just because you have a right to a certain act by me, that I should be liable when the act goes unperformed regardless of the faultiness of my conduct.

Second, what about an explicitly Hohfeldian characterisation of the contractual right? So far, following many rights-based theorists of contract we have implicitly characterised the right as simply a claim to, or over, some subject-matter. Hohfeldians would insist on characterising the right 'correlatively' so that it corresponds to a duty on the part of another particular person. (Wesley Newcomb Hohfeld, Fundamental Legal Conceptions as Applied in Judicial Reasoning (Walter Wheeler Cook (ed), New Haven: Yale UP, 1919) 38.) So if you have a right to the provision of a shed, some other person owes a duty that is discharged if the shed is provided. Yet this approach does not resolve our difficulties either. It does not explain why the quality of the defendant's conduct should be irrelevant to liability for the breach of a contractual right. Yet relevant, by contrast, to liability for breach of a property right.

Third, perhaps we could say that a contract confers a right of a special quality — something like: a 'right to performance irrespective of the other party's culpable conduct'. By contrast we might say that a proprietor holds a 'right, against interference through culpable conduct'. This reformulated definition of the respective rights might produce the results we seek in terms of liability. But it renders the rights-based account unenlightening. We have
} 


\section{The character of contractual liability}

Consideration of the rights-based theory has suggested we ought to attend more closely to the character of contractual liability, in order to improve our understanding of our theoretical target. Otherwise we risk constructing a theoretical account that misses the mark. Therefore the article will now reconsider what is distinctive about contractual liability. Relatedly, it consider whether there is in fact a single form of liability that applies to all contracts and not just some of them. This reflection will prompt us to refine our understanding of contractual liability, yielding an appreciation of aspects that theorists have tended to overlook. The reflection will also prove crucial for the article's argument later on, because attention to the peculiar character of contractual liability will point the way towards the development of an alternative theoretical account.

\subsection{Not merely 'strict' but 'automatic'}

We saw at the outset that contractual liability is often said to be 'strict' rather than 'fault-based', prompting legal theorists to go to some lengths to explain or justify the law's approach. However, we have also seen that so-called 'strict' contractual liability may be quite different from 'strict' liability as it appears in other areas of private law, such as the tort of trespass. Let us now develop this point more fully, by identifying what might be distinctive about contractual liability, in contrast to liability in the torts that protect property rights.

An important caveat: the aim here is not to develop a theory of so-called 'strict' liability in private law generally. That would require engagement with a vast literature and is certainly beyond the scope of the present article. The aim is only to develop a clearer picture of contractual liability, in part by thinking about what it does not involve. This picture may be might ask, should the right be defined this way? And why should a property right be defined differently? 
illuminating even if one disagrees with some of the assumptions adopted here about what liability outside of contract law is like.

In the context of tort law, the meaning and appropriateness of the label 'strict' liability is of course hugely controversial. But one reason that various tortious actions tend to be called 'strict' — such as the torts of trespass to goods or land — is because they do not generally require an assessment of the carefulness or reasonableness of a defendant's conduct as an element of the cause of action.42 For example, if I use or detain your car without permission, or walk across your land, I may be liable in an action for trespass regardless of whether my actions were in some sense reasonable. (I may be liable even if, for instance, I reasonably believed that the property in question belonged to me rather than you.) Contrast various causes of action that also protect property rights and that tend to be called 'fault-based'. Exactly what this label is meant to capture is also hugely controversial, but let us merely observe that the main 'faultbased' torts usually require an assessment of the carefulness or reasonableness of the defendant's activity before imposing liability.43 The most prominent examples are of course negligence and nuisance.44 If, for example, I accidentally crash my vehicle into yours, you must generally establish that I failed to take reasonable care in order to hold me answerable for the injury I have done to your property.45 If I emit smoke from my land onto yours, you must generally establish that the emission occurred through an unreasonable use of my land.46

42 Eg Simon Deakin, Angus Johnston and Basil Markesinis, Markesinis and Deakin's Tort Law (Oxford: Clarendon Press, 6th ed, 2007) 389, 405. The authors highlight various uncertainties and complexities related to this proposition.

43 Of course, some would argue that 'fault-based' is a misnomer here because one can be objectively careless without any true moral fault. Eg Holmes, The Common Law n 7 above, 107-108; Tony Honore, 'Responsibility and Luck: the Moral Basis of Strict Liability’ (1988) 104 LQR 530. This does not affect the point above, which is only that torts such as negligence and nuisance generally involve an assessment of the reasonableness of the defendant's conduct.

44 See eg Deakin et al, above n 42, 414 (discussing 'reasonableness' in nuisance and negligence law).

45 Of course in certain circumstances you may invoke the doctrine of res ipsa loquitur.

46 Though if the emission causes a material injury to your property I may be liable without further inquiry. St Helen's Smelting v Tipping (1865) 11 HLC 642; 11 ER 1483. 
Crucially, however, contractual liability is in a sense much 'stricter' than any of the other private law causes of action just mentioned that address interferences with property rights. This includes not just the so-called 'fault-based' tort actions such as negligence and nuisance, but even the so-called 'strict' liability actions such as trespass to land or goods. This is because, in all of the actions just discussed, the defendant's liability generally depends in some way upon the quality of her conduct or activity (in very broad senses of those terms) in connection with the alleged injury. That is to say, the defendant's liability depends upon a consideration of her act, omission, use, or other activity that has brought about the injury of which the claimant complains. Contractual liability, by contrast, does not require any such investigation. Let us now develop these points.

Even a 'strict' liability tort generally requires some sort of assessment of the defendant's conduct or activity in connection with the breach of which the claimant complains. For example, if you sue me in trespass for detaining your goods, the reasonableness of my conduct may well be irrelevant; still, you must establish that I have for example used, or detained, or simply come into possession or control of a piece of your property. Likewise, if you sue me for walking across your land, it may well be irrelevant whether my conduct was in some sense reasonable; still, the quality of my conduct will be relevant in other ways. For one thing, you must prove that I performed some action or activity that amounted to an incursion upon your land - such as walking across it. I may escape liability if my relevant behaviour was unintentional, or at least non-volitional - if, say, I was pushed by a third party across your boundary.47 Moreover, in all of these actions, you must generally establish that my act, omission, or other activity was causative of the injury of which you complain. In a very broad sense, then, a defendant's liability in all of these torts depends upon the quality of her conduct or activity in connection with the alleged injury. 
Liability for breach of contract is striking because it does not essentially require any assessment of the conduct on the part of a defendant that brings about the breach of which the claimant complains. Instead, given the mere fact that the contractual performance is defective in some way, the defendant contracting party's liability may follow automatically. For example, if I contract to provide you with a brand new garden shed, the mere fact that you do not receive a shed, or receive one that is somehow deficient, may suffice to establish my liability for contractual breach. A court need not assess whether my relevant conduct in connection with the breach was reasonable or careless. Nor whether my behaviour amounted to some kind of unwarranted use, detention, or possession. Nor need a court consider whether I brought about the breach intentionally, or volitionally. Indeed, the court need not even consider whether my conduct was responsible for causing the breach of which you complain. (I may be liable even if the actions of a third party caused the contractual performance to be defective.)

For these reasons, a better term for so-called 'strict' liability in contract law might bewith due apologies for a neologism — 'automatic' liability. This term could be used to single out a form of liability that does not depend upon any assessment of the defendant's conduct that may have brought about the alleged breach or injury.48 This term would fasten on what is striking about the contractual context, and avoid conflating it with other kinds of liability in private law.

\subsection{Is 'automatic' liability common to all contracts?}

Still, one might question whether the distinctive 'automatic' approach to liability just identified is applicable across the whole of contract law-whether it is common to all contracts. The article will now suggest that it is, and in so doing further elucidate the peculiar character of frustration - the position associated historically with Paradine v Jane (1647) Aleyn 26, Style 47; 82 ER 897. 
contractual liability.

Someone might suggest that not all contractual liability is 'automatic' because some contracts evidently create rather less strenuous or onerous obligations than others. For instance, many contracts require a party only to provide a service or product that is reasonable. The usual example is a doctor who contracts to perform a difficult surgical operation. She will ordinarily be obliged not to cure the patient, but to operate with reasonable care and skill.49 Many other contracts for professional services create similar obligations to act reasonably or nonnegligently. More generally, depending upon how any given contract is drafted by the parties, or construed by a court, it may impose only a reasonableness standard of performance-or indeed, some other less onerous standard. For example, a given contract may be drafted so as to require a party merely to provide a service or product that reflects best efforts, or good faith endeavours, basic professional competence, minimal merchantable quality and so forth.50 In fact, the possibility for variation here is apparently endless. So it might now seem that the law of contract presents us, not with a single standard of liability—'automatic' or otherwise—-but rather with a profusion of different standards.

Even if contract law did present us with a profusion of different standards of liability, the 'automatic' standard would be something worthy of explanation or justification by a theory of contract.51 Clearly, a significant remainder of contractual obligations are not 'less onerous'. A person who contracts to pay money, or to deliver generic goods, for example, will ordinarily be liable for her failure even if she did everything reasonable or indeed possible on her part to perform.52 Thus, many contractual breach cases simply involve an application of the

49 Lanphier v Phipos (1838) 8 Car \& P 475; 173 ER 581. See also the Supply of Goods and Services Act 1982, s 13 (implied term that a service supplied in the course of a business will be reasonably careful and skilful). 50 See further E Allan Farnsworth, 'On Trying to Keep One's Promises: The Duty of Best Efforts in Contract Law' (1984) 46 University of Pittsburgh Law Review 1 (1984).

${ }_{51}$ Cf Smith n 2 above, 383-384.

52 See eg GH Treitel, 'Fault in the Common Law of Contract' in Maarten Bos and Ian Brownlie (eds), Liber Amicorum for the Rt Hon Lord Wilberforce (Oxford: OUP, 1987) 186-194. 
'automatic' approach. That approach, even if does not apply across the whole of contract law, is a particularly striking, and arguably paradigmatic, form of contractual liability. The present article might therefore be taken as an account of this form of liability, even if it is merely one form among many.

However, the article will now venture a more ambitious claim: despite the admitted variability in the onerousness of contractual obligations, an underlying 'automatic' liability standard must apply to all contracts. Even where a contract creates a less onerous obligation, such as to provide a reasonable service or product, liability for the obligation's breach remains, fundamentally, automatic.

To see why one might suppose that all contractual liability is fundamentally automatic, notice first of all that even those contractual obligations that are admittedly 'less onerous' are often accompanied by a sort of residue of automatic liability. For example, a surgeon is obliged only to use reasonable care in operating on a patient—but what if she fails to operate on the patient at all, say because she reasonably though mistakenly operates on another instead? It seems she will be automatically liable for that failure. At least, the case law indicates that such an approach applies to other professionals, such as a valuer who values the wrong property, a lecturer who delivers the wrong lecture, a portraitist who paints the wrong person and so forth.53 Or to take another example, a shipbuilder may be contractually obliged to deliver only a seaworthy ship — one reasonably fit for seafaring. However, she will be automatically liable for the failure to deliver such a ship: she cannot escape liability by showing that the ship turned out to be unseaworthy through no fault of her own, for example due to an unforeseeable defect in the manufacturing process.54 These kinds of case suggest that 'automatic' liability may somehow be at work in all contracts and not just some of them.

53 Platform Funding v Bank of Scotland [2009] QB 426, 443-444.

54 See Michael Bridge, The Sale of Goods, (Oxford: OUP, 3rd ed, 2014) [7.96-7.97]. 
But here is the point that appears dispositive in favour of the view that all contractual liability is fundamentally 'automatic'. Consider again a less onerous contractual obligation, such as to conduct a surgical operation with reasonable care. Notice that a court considering liability for a breach of such an obligation will tend to make a crucial assumption. The court will assume that, if the obligation is breached-because the operation is not reasonably careful-liability can be sheeted home to a particular person: the contracting party who undertook to perform. This is a hallmark of automatic liability.

Imagine that an automatic liability standard did not apply to a contractual obligation to operate with reasonable care. Then, when the operation was performed unreasonably, we could not assume that the contracting party who undertook to provide the operation should be liable. Rather, liability would all depend - on whose conduct, if anyone's, happened to cause the operation to be unreasonable. A substandard operation might be attributable, for example, to the culpable conduct of a surgeon, a nurse, a janitor, a hospital manager and so on. Whoever it turned out to be, they would not necessarily by the party who undertook to provide the operation. Only if contractual liability is fundamentally automatic_only if we can establish a party's liability without investigating the quality of her conduct in connection with the breach - are we entitled to assume that the party herself, rather than somebody else, should be liable. Hence an automatic liability standard must apply to all contractual obligations, even the least onerous.

To put this point another way, there is an intimate connection between contract law's treatment of liability and a basic principle of contractual privity: the principle that only the party who has undertaken to perform a contractual obligation, and not anybody else, will at least in the first instance be the person answerable for its breach.55 Only if contractual liability note 79 below and accompanying text. 
is fundamentally automatic can we account for this principle-for the law's identification of one particular person, along amongst all the world, as liable for breach, prior to any investigation of her relevant acts or omissions that might have produced the breach.

We need some way to encapsulate the results of this reflection on the character of contractual liability, i.e., the conclusion that liability is fundamentally and invariably 'automatic' (independent of any investigation of conduct in connection with the breach), even though the onerousness of a particular contract may vary, depending upon how it is drafted or construed. One way to do so is by distinguishing the subject-matter or content of a particular contract, on the one hand, from the general rule or form of contractual liability, which applies to all contracts, on the other. A contract's subject-matter or content is what exactly the parties must do or provide. How to define this is essentially up to the parties themselves, as well as the court which must construe their agreement. Parties may if they like stipulate-expressly or implicitly-for the provision of a successful operation, or a brand new garden shed; alternatively they may stipulate for a merely reasonable operation, or a satisfactory shed. But then, given the underlying automatic form or rule of liability that applies to all contracts, the party who fails to provide the defined contractual subject-matter, whatever it happens to be, is liable. We can reach that conclusion without further investigating her conduct.

\subsection{Frustration, impossibility and hardship}

Finally, it is worth distinguishing the standard of contractual liability, our theoretical target, from certain other contractual doctrines: the defences of frustration, impossibility, and hardship. These doctrines to some extent ameliorate the strenuousness or onerousness of contractual obligations, and so it might be thought that they should affect our understanding of the standard of contractual liability. However, while there is substantial controversy about the nature and scope of these doctrines, they are best viewed as conceptually distinct from the standard of contractual liability, because they do not directly address the question of whether 
a party should be answerable for a contract's breach.

At least on one conventional view the frustration doctrine concerns, not whether a party should be answerable for a breach of her contractual obligation, but whether her obligation should continue to exist in the light of changed circumstances. Frustration might occur, for example, where two parties contract to hold concerts in a particular music hall, but the hall is then razed by an unpreventable fire.56 Performance in these changed circumstances is something radically different from what the parties initially anticipated,57 and so it may be appropriate to call off, or in the jargon 'discharge', their contractual obligation. Contrast this with the inquiry into a party's liability for breach. That inquiry necessarily presupposes that a party's contractual obligation continues to exist-such that one can ask whether it has been breached and whether the party is legally answerable for the breach.

Frustration is sometimes associated with the notion of 'impossibility', though it is clear that impossibility does not suffice for frustration.58 Impossibility may, however, be raised as a defence to specific performance, and certainly a party may resist specific performance on the related ground of extreme hardship.59 Yet, the better view is that such a defence does not bear on the standard of liability for contractual breach. Specific performance will be declined where performance is impossible or extremely hard because in these circumstances it is inequitable or otherwise inappropriate to award that remedy. The appropriateness of a specific remedy for breach is a distinct question from the inquiry into liability, which determines whether one is answerable for a breach in the first place. Hence if a party makes out a hardship defence to specific performance the court may still order her to pay damages.60

56 Taylor v Caldwell (1863) 3 B\&S 826; 122 ER 309.

57 Davis Contractors v Fareham Urban District Council [1956] AC 696, 728-729.

58 Taylor $v$ Caldwell $\mathrm{n} 56$ above, 833.

59 Patel v Ali [1984] Ch 283.

60 ibid 288. The obliged party's culpable behaviour may also make specific performance more likely, Sang Lee Investment $v$ Wing Kwai Investment (1983) 127 SJ 410, but again this goes to the appropriateness of the remedy rather than answerability for breach. 


\section{A promissory account of contractual liability}

The groundwork has now been laid for an alternative account of contractual liability. The foregoing discussion should lead us to see the attractions, in the present context, of another very familiar theory of contract law: the theory of contract as promise. 61

The nature of a promise is of course controversial among philosophers and other theorists, as is the relation between purely moral promises and contract law.62 Suffice it to say there appear to be various important differences between purely moral promises and legally binding contracts. The present article will not seek to resolve these broader debates about the relation of promise to contract, let alone about the nature of promises more generally. The aim here is relatively modest: to sketch one not implausible view of promising, an appreciation of which may help us to bring, by way of analogy, the nature of contractual liability into focus. The article will not so much argue in favour of a promissory theory as suggest that, once we are sufficiently clear about what we are looking for from an account of contractual liability, this kind of theory should fall into place.63

So far the article has suggested that a number of existing theories of contractual liability-Holmesian, instrumental and voluntarist theories-while they have other merits, suffer in various respects because they do not regard a contractual obligation to perform as having intrinsic normative significance.

A rights-based theory does attempt to link contractual liability to the inherent normative significance of a contractual obligation to perform. However, this theory is less than fully

6161 The classic contemporary exposition is of course Charles Fried, Contract as Promise (Cambridge, Mass: HUP, 1981). More recent discussions include the work of Dori Kimel eg From Promise to Contract (n 36) and Seana Shiffrin, eg 'Is a Contract a Promise?' in Andrei Marmor (ed), The Routledge Companion to Philosophy of Law (New York: Routledge, 2012) and many of the essays in Klass et al n 31 above.

62 Eg ibid.

63 As Christine Korsgaard observes in another context, sometimes 'a sufficiently detailed and accurate description of the problem actually yields the solution'. 'Realism \& Constructivism in Twentieth-Century Moral Philosophy' (2003) 28 J Philosophical Research 99, 115. 
satisfactory because it does not properly attend to the special character of contractual liability, as opposed to liability in other areas of law such as the torts that protect property rights.

If we do attend more closely to the special character of contractual liability, we can see that it is not merely 'strict' (at least as that term is often used) but 'automatic': a party's liability for breach does not essentially depend upon any investigation of her conduct that may have brought the breach about. At the same time, exactly what a particular contract requires in terms of performance varies from case to case, because contracting parties have substantial leeway to define the contract's 'subject-matter' - what it is that must be done or provided.

In sum, then, we are looking for a theory of contract that 1) recognises a contractual obligation's inherent normative significance; 2) is capable of explaining why liability is not essentially dependent upon the conduct that produces a breach; and which at the same time 3) allows parties to define the subject-matter of their contractual obligation, i.e., what exactly amounts to performance in a given case. Those criteria can be met by a promissory theory.

First of all, it is plausible to think of a promise as creating a certain sort of intrinsically significant normative obligation. At least on one plausible view, a promise is a normative undertaking, assurance, or commitment issuing from a promisor to a promisee with respect to some subject-matter. By promising, I make an ongoing normative commitment such that I become morally obliged to perform and answerable to you if I do not. So if I promise you, say, a garden shed or a medical operation, the provision of the shed or the operation becomes obligatory for me, and if I do not provide it you have a legitimate ground for complaint. A promise, then, in itself supplies a reason to hold the promisor morally answerable (or 'liable') for its breach.

Secondly, a promissory theory can explain why liability is not essentially dependent upon the conduct that produces a breach. As we have seen, a promise supplies a reason to hold the promisor morally answerable for breach. Moreover, at least on one plausible view, this 
reason is not essentially based upon a judgment about the promisor's conduct at the time of the breach. Rather, the essential reason the promisor is answerable is just because the promissory assurance that she provided has fallen through. Answerability here is based upon the failure of the promise, rather than upon some other form of culpable conduct. Hence if I fail to provide, say, a promised garden shed or medical operation, the fundamental reason I am morally answerable is that my promissory undertaking has fallen through.

The view that promissory liability essentially arises just because of the failure of a normative assurance-rather than because of some other kind of culpable conduct-is hopefully intuitive. But we can also adduce one important piece of evidence in favour of this view. Imagine that someone complains they have been the victim of a breach of a purely moral promise. (Perhaps a friend promised to drive them to an appointment but did not show up.) In this kind of case we are likely to make a telling assumption. We will assume that, if there has been a breach, one particular person may at least prima facie be called to account, morally speaking: the promisor. She may be called upon, at the very least, to explain why she did not make good upon her undertaking. Notably, we will make this assumption about the promisor's answerability without first investigating the quality of her conduct—let alone anybody else's conduct - in connection with the alleged breach. Yet, we would not be entitled to do this if promissory liability was essentially based on the character of the conduct that produced a breach. If that were the case, then before assuming that any particular person was morally answerable, we would first have to investigate whose conduct, if anyone's, brought the breach about. In other words, just as we saw earlier that there is an important link between contractual liability and contractual privity, there appears to be an analogous link between promissory answerability and what we might call promissory privity: our ability to single out one particular person, the promisor, as potentially answerable, without investigating anyone's conduct. 
Thirdly, a promissory theory can account for the fact that parties are free to define the subject-matter of their obligation, i.e., what exactly amounts to performance in a given case.64 It is plausible to suppose that a promisor may undertake, for example, to achieve a result, or merely to use reasonable efforts, good faith efforts, or the like. In this respect too, moral promissory liability seems analogous to contractual liability.

Crucially, then, the claim of this article is not that promissory liability is 'strict' rather than 'fault-based'. A promisor may in many cases be absolved of wrongdoing if she can show that her conduct was not faulty (intentional or unreasonable for example). This is because exactly what a promise requires of the promisor in terms of performance will vary from case to case, depending on what she undertakes, explicitly or implicitly, to do or provide. The article's claim here is more fundamental: that promissory liability is essentially automatic, arising from a failure of the promisor's normative undertaking, rather than from the promisor's culpable conduct that may have brought about a breach.

Relatedly, it is important to note that the claim here that promissory liability is 'automatic' is fully compatible with the view that many purely moral promissory obligations are not 'enormously strenuous' or onerous.65 Furthermore, the claim here is also compatible with the view that purely moral promissory liability is in many ways less strenuous than contractual liability. Seeing why this is the case will bring out some further commonalities between promissory and contractual liability.66

For one thing, purely moral promissory undertakings may tend to be less strenuous because undertakings to achieve a specific result may be relatively rare outside of the legal contractual context. While a purely moral promisor may sometimes undertake to achieve a

64 This view of promising is endorsed by Dori Kimel, 'Personal Autonomy' n 31 above, 103-108; and Seana Shiffrin, 'Strict Liability' n 20 above, 362-364. However, for the reasons discussed below, Kimel and Shiffrin do not appeal directly to a promissory view to account for contractual liability.

65 GEM Anscombe, 'On Promising and its Justice, and Whether it Needs Be Respected In Foro Interno' (1961)

3 Crítica $61,70$.

${ }_{66} \mathrm{Cf}$ text to note 56. 
specific result, for example where that result is especially important to the promisee (I might promise to pick you up at a precise time of day in order to drive you to a job interview), more often the precise contours of the promisor's obligation will be left unspecified. Indeed, it would often be incompatible with the spirit of the parties' relationship to demand too precise a specification of a purely moral promissory obligation. If I express my willingness to build a garden shed for you gratis, for example, it would probably be inappropriate for you to insist on a precise construction timetable.67

Furthermore, it is plausible to think that there is a sort of moral equivalent, in the promissory context, of the frustration defence in contract law. When circumstances change, this may mean that a promissory obligation is called off or 'discharged'. While in some cases a change of circumstances may mean that a moral promise ought to be called off in its entirety, in other cases the change may merely diminish the weight of the promise in moral reasoning, such that it exerts less influence on decisions about what the promisor ought to do, all things considered, and about what the promisee can legitimately demand of her. Moreover, it seems likely that a purely moral promissory obligation may be more prone than a contractual obligation to being overridden, undermined, or outweighed when circumstances change. 68

Finally, a purely moral promisor's 'liability' is of course usually associated with less draconian normative consequences or remedies than contractual liability. Sometimes the most severe response appropriate for a breach of a purely moral promise may be an expression of mild reproach or disappointment from the promisee, or perhaps a swift apology from the promisor. Certainly, the suggestion that a noncontractual promisor should be compelled to provide specific performance, or to pay damages, is likely to be wrongheaded. (If a friend tells

67 This is consistent with viewing a mere 'promise to try' as pathological in some circumstances. See Berislav Marušić, 'What's Wrong with Promising To Try?' (2017) 98 Pacific Philosophical Quarterly 249, and works cited therein.

68 Arguably 'a mere small degree of inconvenience exempts us' from the obligation of a purely moral promise. Anscombe, 'On Promising' n 65 above. 
you they will be late for a promised dinner, it would be inappropriate to frogmarch them to the restaurant or to demand a cash payment by way of compensation.) Sometimes the provision of a close substitute for the promised performance may be appropriate, but relatively minor hardship or difficulty in finding a substitute (not to mention 'impossibility') may also exclude the operation of this remedy in the purely moral context.69

All this is consistent with the view that, if and to the extent a promissory obligation holds, the promisor's answerability for breach arises, in the first instance, just from the failure of a normative undertaking on her part, rather than on the basis of a judgment about her later conduct that may have caused the failure. If this view of promising is plausible, we have reason to suppose that contractual liability and promissory liability are analogous.

\subsection{Comparison with other theories}

It will now be useful to contrast the promissory account of contractual liability with the other existing theories discussed previously. This will highlight some advantages of the promissory view. It will also show that this view is potentially compatible with a rights-based theory of contract, and so the two theories may usefully supplement each other.

First, on the promissory account a contractual promisor does not make a Holmesian 'dual undertaking': to perform, or in the event performance does not occur, to compensate the promisee. She simply promises to perform. The failure of the contractual promise itself is the source of her 'automatic' liability. Thus, the promissory account does not strike the difficulties a Holmesian theory faces in seeking to derive the liability standard from a party's supposed secondary undertaking to pay damages.

One possible motivation for the Holmesian view of contractual liability is the thought that, because a contracting party cannot make it pragmatically certain that performance will

${ }_{69}$ Of course this engages the issues discussed by eg Neil MacCormick, 'The Obligation of Reparation', in Legal Right and Social Democracy (Oxford: Clarendon Press, 1982) 212; John Gardner, 'What is Tort Law For? Part 1. The Place of Corrective Justice' (2011) 30 Law and Philosophy 1, 28-48; Kimel, 'Personal Autonomy' n 31 above, 104-105. 
occur (even the best-laid plans are sometimes thwarted), the most she can do, in order to produce something like strict liability, is make a conditional undertaking to compensate her counterparty in the event performance fails. 70 However, this assumes that the significance of the contractual undertaking must lie in its provision of a sort of pragmatic certainty. The view advocated here is that the essential significance of a promise is that it is a normative assurance or commitment. A promisor's normative commitment to perform may be unconditional, even if she cannot be pragmatically certain she will make good on it.71

Unlike an instrumental theory, the promissory account does not seek to explain or justify strict liability by appealing to an independently valuable end, such as economic efficiency or a separately specifiable moral goal, which contractual liability might help to produce. Thus, the account is not contingent upon the circumstances in the same way as an instrumental theory.

One might object that a promissory account of contract is instrumental because it views contract law as 'merely a means of enforcing' a moral promissory obligation 'that arises independently of it'.72 While such an objection might be valid as against some promissory theories of contract, it would be misplaced as against the view propounded here. The claim here is not that contract law is a means for enforcing purely moral promissory obligations. It is that we can understand contractual liability by drawing an analogy to promissory liability. The analogy enables us to see that in both cases liability is based just upon the failure of a normative undertaking.

Although the account advanced here is not instrumental, it need not deny that contract law (and indeed the practice or institution of contracting generally) might have instrumental

70 Suggested to the author in person by Stephen Smith.

71 Of course this is not to take a position on the difficult question of whether one can plausibly promise, or contract, to do something that is clearly impossible from the outset. For discussion of this and related issues from the legal perspective see eg James Gordley, Foundations of Private Law (Oxford: OUP, 2006) ch 15. 72 Weinrib, Idea of Private Law n 16 above, 52. 
value. It seems likely that contracting is valuable for all sorts of instrumental reasons. The account advanced here denies only that we need appeal to such instrumental values in order to understand the law's approach to contractual liability.

The promissory theory of contractual liability is also distinguishable from a voluntarist theory. To be sure, a promise is a kind of voluntary undertaking. Indeed, individuals seem to be largely free to choose the subject-matter of their promissory obligations, and this may be to some extent comparable to other paradigmatically arbitrary choices such as the decision to paint a wall a certain colour. At the same time, it is plausible to suppose that the choice a promisor makes is not wholly arbitrary because it occurs against the backdrop of a normative scheme that is not up to her to choose. In the moral promissory context, this normative scheme may be supplied by the practice or institution of promising.73 It provides a set of socially established rules, which confer on an individual act of promising its characteristic normative effects - in particular, the creation of a certain kind of obligation and concomitant liability upon the promisor. On this view, then, a promisor does not exercise a sort of ungrounded faculty of choice or voluntariness, but participates in and is bound by the rules of an established normative practice. Again we may risk the analogy of participation in a game such as baseball. A promissory understanding of contract is likewise capable of avoiding the difficulties that afflict a purely voluntarist account, because it can appeal to the institution or legal practice of contracting — which supplies rules that bind individual contracting parties and confer on their voluntary actions a certain normative significance. Of course if one takes this view, a number of further questions immediately open up. One might wonder for example to what extent the institution of contract is constituted by positive law such as statute and case law, and to what extent by other social behaviour, custom, or practice. In addition, one might suppose

73 Rawls n 29 above. Of course this point is philosophically significant because it engages the debate between practice-based accounts of voluntary undertakings (represented by for example Hume n 28 above, Anscombe, nn 28 and 65 above, and Rawls) and opponents of such accounts (such as MacCormick and Scanlon n 29 above). Obviously there is more to be said about this. 
that the appeal to the idea of a normative institution or practice cannot be the end point of an account of contract law, because we must proceed to ask whether and why the institution is a valuable one to have.74 Still, a theorist who embarks on this sort of inquiry will evidently produce a very different account of contract as compared to a theorist who propounds a bare voluntarist account that simply appeals to individual choice or agency.

Finally, the relation between a promissory theory and a rights-based theory requires elaboration. A promissory theory is potentially compatible with, and so can supplement, a rights-based view. Indeed, the combination would appear to be valuable, because it allows each account to take advantage of the other's theoretical virtues. As we have seen, a rights-based theory is arguably capable of reconciling judicial intervention in contract cases with the "harm principle'.75 But only the promissory view is capable of accounting for the contractual liability standard.

A promissory theory of contract is potentially compatible with a rights-based theory because, at least in the legal contractual context, a promissory undertaking of a certain performance might be said to ground a legal 'right' on the part of the promisee to that performance.76 Without attempting to settle on a definition of a 'right', we might suppose that a contractual promisee acquires some sort of recognised interest, legitimate expectation, or claim to the contractual subject-matter. Indeed, this interest is similar-in some respects - to a property right. The contractual promisee of a garden shed is analogous to the proprietor of a garden shed in that he can reasonably expect to enjoy and benefit from the shed, to have it within his normative control, and so on.

74 For analogous inquiry into the practice of promising, see Rawls, ibid; Anscombe, 'On Promising' n 65 above, 73-78.

75 See text to note 32 above.

76 Perhaps the most famous exponent of this kind of view is Grotius, The Law of War and Peace (FW Kelsey (trans), Oxford: OUP, 1925) book II, chapters XI-XII. See further Peter Benson, 'Grotius' Contribution to the Natural Law of Contract' (1983) 6 Canadian Journal of Netherlandic Studies 13. Some accounts of noncontractual promises view these too as conferring a sort of moral right on the promisee. See eg David Owens, 'Does a Promise Transfer a Right?' in Klass et al, above n 31. 
While, as we have seen, a 'rights-based' theory cannot in itself account for contractual liability, such an account becomes possible if we supplement the rights-based theory with a promissory view. If a contract involves a promissory assurance issuing from the promisor, then any 'right' a contract creates will differ from other kinds of rights - in particular, property rights - in at least one crucial respect. The rightful interest, expectation, or claim that a contract creates will be grounded in a promise, which supplies the normative basis or reason for the promisee's entitlement.77 Contrast a typical property right. While the normative basis of such a right is a matter of perennial controversy among property theorists, one thing is clear: a proprietor's right to a certain object of property is not typically grounded in a promissory assurance issuing from another person. 78

With this understanding of the difference between contract and property 'rights' in place, we can account for the law's different treatment of liability in the contractual and proprietary contexts. Consider the proprietary context first. Here, as we have seen, a defendant's liability generally requires an investigation of the conduct that has brought about an injury to the claimant's property. Torts that address property interferences, such as negligence, nuisance and trespass, generally require a court to consider whether the defendant has carried out some unreasonable, intentional, volitional, possessory, or other causative behaviour, which has brought about the injury of which the claimant complains. So if, for example, you are the proprietor of a garden shed that burns to the ground, that in itself does not provide reason to hold me liable; but there may be such a reason if I have, say, intentionally or unreasonably caused the fire. Since your property right is not grounded in an assurance issuing from another particular person, the law must look around, as it were, to examine persons'

77 At least in a typical case, it supplies the only normative basis. The promisee has no other reason to suppose he will come to enjoy the promised performance.

78 It is hoped that the notion of a promise 'grounding' - supplying the normative basis or reason for-a contractual right can be grasped without further explanation. But for a very helpful introduction to the notion of grounding and a survey of recent philosophical work see Selim Berker, 'The Unity of Grounding' (2018) 127 Mind (forthcoming) pt 2. 
conduct in order to find a reason to hold someone liable for the injury. Consequently, liability in this context is not 'automatic' but conduct-based. Furthermore, since anyone in the world whose conduct or activity interferes with the subject-matter of a property right is potentially liable, we can say that a property right holds 'against the world'.

Next consider the contractual context. Here the contractual promisee may, if we like, be said to have a 'right' to the contractual performance. However, this right is grounded in a promise issuing from a particular person, the contractual promisor. Now let us imagine that the performance supplied is defective. Perhaps a brand new shed was contracted for, but the shed supplied is old and dilapidated. In order to find a reason to hold someone liable for this defect, must we investigate persons' relevant conduct, in order to see whether it amounts to a culpable form of interference with the subject-matter of the promisee's right? We need not, because we already have another, different reason to hold at least one particular person liable. We have reason to hold the promisor liable, regardless of the character of her conduct, merely because her promise of performance has failed. Thus, the promisor's liability is 'automatic' rather than conduct-based. Furthermore, as the promisor is the only person who provided a promissory assurance, she is singled out, alone amongst all the world, for liability. Hence the basic principle of contractual privity that it is, at least in the first instance, the contractual promisor rather than anybody else who is liable to ensure that performance occurs.79

In sum, on this approach the different treatment of legal liability in the contractual and proprietary contexts turns out to be the difference between, on the one hand, liability arising

\footnotetext{
79 While the contractual promise itself supplies reason to hold the promisor liable, there may in addition be other reasons to hold other persons liable. For example, the culpable conduct of a third party may amount to tortious interference with contract. On the view advocated here, this form of liability is more akin to a property rights violation than ordinary contractual liability.

This article will not address the other aspect of the privity principle: that only the promisee is entitled to performance. (A common law position that is of course complicated by, inter alia, the Contracts (Rights of Third Parties) Act 1999.) On the difficulties of third party recovery for a promissory theory of contract see eg Stephen Smith, 'Contracts for the Benefit of Third Parties' (1997) 17 OJLS 643. Nonetheless, third party recovery may be explicable on a promissory theory if the promisee can be conceived as holding the promised benefits on behalf of the third party, for example as an agent or trustee.
} 
from a breach of promise, and on the other, liability based on a defendant's conduct or activity that disrupts an entitlement not grounded in a promise. Although both contractual and proprietary claimants may be said to possess certain 'rights', legal liability for the breach of each kind of right works differently due to the grounding of the contractual right in a promise.

\subsection{Why have others not advanced a promissory view?}

One last question remains to be addressed. If a promissory theory can account for contractual liability, why have other theorists not developed such a view? This question is particularly pressing because some of the theorists whose work we have considered —in particular, Smith, Shiffrin and Kimel — are justly renowned for their sophisticated treatments of, among other things, the relationship between contracts and promises. Yet, in their efforts to account for contractual liability, these theorists appeal to quite different ideas: Holmesian 'dual undertakings', the promotion of 'morally healthy relationships', and the promisee's 'right' to contractual performance.

The proximate reason for our theorists' unwillingness to invoke a promissory account may well be their perception of the proper target of a theory of contractual liability. These theorists set out to account for why contractual liability is - at least often, or as a default matter-'strict', in the sense of not 'fault-based', where 'fault' means something like intention or carelessness.80 Having taken 'strict' liability in this sense as their target, it is natural to conclude that a promissory theory is unlikely to assist. Because promissory liability is evidently not always 'strict' but sometimes involves an assessment of the promisor's 'fault'. As we have seen, fault may become relevant due to the content or subject-matter of the promise - what the promisor undertakes to do or provide. 81 Consequently, in their efforts to account for contractual 
liability, theorists feel obliged to invoke quite different ideas-such as dual undertakings, morally healthy relationships, or rights.

This article has suggested that theorists of contract law are correct to suspect there is a distinctive rule of contractual liability that ought to be accounted for. But it is not a rule of 'strict' liability_if 'strict' means liability which excludes consideration of 'fault'. Contractual liability is both more and less 'strict' than that. It may involve, in any given case, an assessment of the faultiness of the defendant's conduct, but it does not essentially depend upon any investigation of the defendant's conduct in connection with the breach at all. Theorists of contract law have tended to ask: 'why does a contractual defendant's liability not require faulty conduct?'. They should ask: 'why is a contractual defendant's liability not essentially based upon an investigation of her conduct?' The latter question targets the aspect of contractual liability that is arguably common to all contracts, and distinctive of contract as opposed to other areas of law. The present article has termed it 'automatic' liability, in order to capture its distinctive quality and to avoid confusion over the term 'strict'. As soon as we explicitly make this particular form of liability our theoretical target, the possibility of a promissory account should come clearly into view. 82

It is natural to assume that the proper target of a theory of contractual liability is socalled 'strict' (i.e. non 'fault'-based) liability if one carries over into contract law certain assumptions about liability from other domains of law and morality. There is a familiar way of thinking about legal liability we sometimes employ when reflecting upon certain tort cases, such as where one person damages another's property. We also employ this model when

\footnotetext{
82 Kimel briefly considers whether there is an underlying 'strict' form of liability common to all promises. He concludes that, if there is, it is of limited 'interest or analytical import'. 'Personal Autonomy' n 31 above, 107. Kimel notes that we might characterise someone who promises, say, not to intentionally overcharge a customer, as 'strictly liable' for intentionally overcharging. However, Kimel doubts the significance of this point because the offence of murder could likewise 'be said to impose a strict liability for killing with intention'. This article has focused on a deeper disanalogy between Kimel's promissory and murder examples. The murderer is presumably liable because of her injurious conduct - because she has performed an act of intentional killing. Whereas the promisor is liable just because of the failure of her promissory undertaking. This point is of interest and import at least if we seek to understand the form of liability that appears in the law of contract.
} 
reflecting on cases of alleged criminal wrongdoing, for example where one person kills or wounds another, or indeed cases of purely moral wrongdoing, such as where one person misleads or insults another. In these contexts we will often ask whether the alleged wrongdoer's answerability should depend upon her 'fault' - upon whether her conduct is, for example, intentional, reckless, or negligent, or accompanied by some other mental state. 83

It is from this perspective that liability for breach of contract may begin to look like a 'puzzle', indeed one that is likely to be 'philosophically interesting'. 84 We may begin to wonder why contractual liability, unlike some forms of tort liability, or indeed criminal liability or moral culpability more generally, is (at least often or as a default matter) 'strict' as opposed to 'fault-based'. Yet, while provoking interest in contractual liability, this way of thinking tends to obscure its essential character. This way of thinking prevents us from noticing the presence in contract law of a very different model of liability. On this model, one does not consider an allegedly wrongful piece of conduct — such as an act of damaging property, or killing, or insulting another person - and then ask what degree of fault must accompany that conduct for liability to be appropriate. Rather, on the contractual model, liability at bottom has nothing to do with wrongful or injurious conduct - faulty or otherwise. Liability here is based not upon a judgment about a party's conduct in connection with a breach, but just upon the failure of her normative undertaking.

\section{Conclusion}

This article has argued that an appreciation of the form of liability characteristic of contract law should lead us back to the familiar theoretical view that a contractual obligation is akin to a promise. This is certainly not to assert that debates about contractual liability, let alone about the nature of contracts or promises, should now be regarded as closed, but rather to point

83 Again the article takes no stand on whether this model is in fact appropriate in other domains. Cf nn $42-43$ above and accompanying text.

84 Notes 5-6 above. See too Kimel, 'Morality of Contract' n 31 above, 225. 
towards a potentially profitable line of further inquiry. Even if the article has not succeeded in making out the case for a promissory view, it has endeavoured to contribute something to our understanding of contractual liability as well as the relative merits of some of today's leading theories of contract. 